\title{
THE RISK AND RETURN PROFILE OF ASIAN REAL ESTATE STOCKS
}

\author{
KIM HIANG LIOW and MONG CHUAN SIM \\ National University of Singapore
}

\begin{abstract}
This research examines the risk and return profile of Asian real estate stocks from an American investor's point of view. Our results indicate that Asian real estate security markets have not produced high levels of compound returns relative to the US REIT and UK real estate stock markets since the 90's. They have also experienced a higher level of volatility compared to their USA and UK counterparts. Asset allocations using meanvariance optimization are difficult to carry out, as many of the Asian property stock markets are not normally distributed. In addition, Asian real estate stocks have been able to provide diversification benefits in international investing that includes the US and UK security portfolios. However, the case for separate allocations to international real estate is weakened by the high correlations that are found in Asian markets between the real estate stock and broader market indexes.
\end{abstract}

Keywords: Asian real estate stocks, market indexes, risk, return, normality, diversification

\section{INTRODUCTION}

Listed real estate companies have become an increasingly important investment vehicle in Asia and internationally (Steinert and Crowe, 2001; Bond et al, 2003), particularly through the success of real estate investment trusts (REITs) in the USA, listed property trusts (LPTs) in Australia, the recent establishment of equivalent vehicles in Japan, Korea, Malaysia, Singapore and Hong Kong and the long-established track record of listed real estate companies in Asia and Europe. With increased allocation of US pension funds to global investments and an expansion in global market capitalization represented by Asian markets, as well as specific events such as the Asian financial crisis and the rise of China as a new economic giant, considerable attention has been given to various aspects of real estate company performance in Asia (Garvey et al, 2001). However, adverse economic conditions have resulted in negative returns for the Asian listed real estate in the late 1990's, leaving international investors to question whether Asian real estate offers investment benefits through superior rates of return and enhance diversification. 
Whilst much of the previous Asian real estate company research has focused on performance analysis and the inter-relationship between the indirect and direct real estate markets in specific countries ${ }^{1}$, few studies have systematically examined the risk and return characteristics of Asian real estate stocks since the 1990's. Given the increasing interest of global real estate funds and US investors in overseas opportunities, this research contributes to and complements previous research by investigating the risk-return behavior and diversification potential of 10 Asian real estate stock indexes over the period 1990-2003. A range of investment issues is examined including the mean return, risk and risk-adjusted performance of the real estate stock and stock market indexes, their conformity to normally distributed return curves and possible diversification benefits. Additionally, the Asian results are compared with those of the UK and USA to shed light on the attractiveness (or otherwise) of Asian real estate as an investment option for international investors.

The remainder of this study is organized as follows. The following section provides a summary of the key findings on the risk-return profiles and diversification benefits of direct and indirect real estate. This is followed by an explanation of the data requirements. Next, the empirical findings relating to return and risk; normality, skewness and kurtosis and diversification benefits are reported. The last section provides concluding comments.

\section{RELATED LITERATURE}

A number of studies have empirically examined the gains associated with diversification in domestic real estate, either across geographical region or property type. To the extent that different categories of real estate are not subject to the same macroeconomic factors, diversification will reduce the unsystematic risk of a real estate portfolio. Accordingly, diversification allows investors to reduce the overall risk level of the real estate portfolio without sacrificing return. Ross and Webb (1985) analyze annual rent indices for 14 countries in the period 1958-1979 and find that direct investment in international real estate may provide a way of achieving an efficient portfolio, since approximately $35 \%$ of the total variation in the country rates of return are explained by variations in the world index. Hartzell et al. (1987) analyze pension funds of real estate investments in the USA for the time period 1973-1987 and find that dividing the US into eight economic activity regions instead of four geographic regions provided superior diversification based on lower correlation coefficients.

\footnotetext{
${ }^{1}$ These studies include Singapore (Liow, 2000, 2001a, 2001b); Hong Kong (Chau et al, 2001; Newell and Chau, 1996) and Australia (Newell and MarFarlane, 1996; Newell and Acheampong, 2001).
} 
In listed real estate, Asabere et al. (1991) examine the risk and return attributes of international real estate equities and find that they offer higher returns as well as greater total and systematic risk than the US REITs from 1980-1988. Additionally, their results indicate that international real estate equities are weakly positively correlated with the return on REITs and outperform them on a risk-adjusted basis. Hence, the addition of international real estate can improve portfolio performance. Eichholtz (1996) finds that diversification benefits from an international real estate securities portfolio are considerably higher than diversification from international equities portfolios generally. Using quarterly and monthly data separately in two studies, Lu and Mei (1999) and Hu and Mei (1999) examine the return-generating process of real estate stock indexes in ten emerging markets ${ }^{2}$ and find that they are more volatile than their respective market indexes and the US NAREIT index. In addition, certain diversification benefits to invest in emerging market property indexes are found, but there is unfavorable asymmetry in the correlation between them and the US index (i.e. correlations are higher during time of volatility).

Gordon and Canter (1999) find that the correlation coefficients between real estate stocks

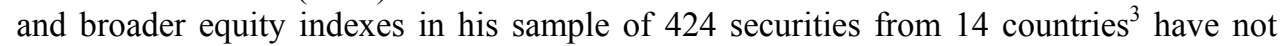
been stable over time and there is some evidence toward integration or segmentation of the listed real estate with the broader equity market. Conover et al (2002) consider whether foreign real estate, when added to a portfolio containing the US stocks and US real estate, is able to produce any further diversification benefits. On the basis of lower correlations between the US stock and foreign real estate, their study suggests some diversification benefits in holding foreign real estate. Finally, Wilson and Zurbruegg (2003) review the literature on the benefits of diversifying property assets (including securitized real estate) internationally. Based on the studies reviewed, they conclude that investors holding a portfolio of international real estate can help diversify risk. However, the extent of diversification benefits that can be achievable through other financial instruments requires further research.

In summary, key findings of previous work are that securitized real estate indexes are more volatile than their respective market indexes and that diversification into international real estate provides a way of achieving an efficient portfolio by a reduction in the variance of returns and an enhancement of portfolio performance. Moreover, diversification across different markets and regions can result in more efficient portfolios. While much work has been done in this area, there has been a lack of research focusing on the Asian region. This study updates and extends the research to ten Asian real estate

\footnotetext{
${ }^{2}$ The ten emerging markets are Argentina, China, Hong Kong, Indonesia, Malaysia, Philippine, Peru, Singapore, Thailand and Turkey.

${ }^{3}$ The 14 countries are Hong Kong, Singapore, Malaysia, Japan, Australia, UK, France, Spain, Canada, USA, Netherlands, Sweden, Switzerland and Germany. The study period is from 1984 to 1997.

Pacific Rim Property Research Journal, Vol 12, No 3 
stock markets through evaluating their risk-return performance and comparing their correlation profiles with the real estate security and stock market indexes of two developed markets, the US and the UK. The study thus complements the international real estate literature on performance measurement and portfolio diversification.

\section{RESEARCH DATA}

The ten Asian markets analyzed are Singapore, Hong Kong, Malaysia, Philippines, Thailand, Indonesia, China, Korea, Taiwan and Japan. Among them, Japan is the only developed real estate market and has a long history of listed real estate. The raw data are the monthly dollar-dominated real estate stock and market index returns for the period from January 1990 through June 2003. In addition, these Asian markets, many of which are emerging markets, are compared with two developed real estate security markets, the US and the UK. For the US, the S\&P 500 is used as the market index and the NAREIT is used as a proxy for the US property market. For the UK, the FTSE All Share and the FTSE Real Estate are used respectively. Finally, it is to be noted that the US listed vehicle (i.e. REITs) is different from real estate stocks of other countries in the study (i.e. real estate companies in the UK and Asia). All the index returns are expressed in term of the US dollar, so adjusted for foreign exchange fluctuations and facilitated cross-country comparison. As such, the perspective of the US investors is assumed in this study. All data are extracted from Datastream.

Tables 1 and 2 contain a description of the real estate stock indexes and stock market indexes, which vary in terms of number of firms constituting the index and market capitalization. Of them, three Asian real estate markets have incomplete data for the study period. Philippines has 104 observations (from October 1994), Indonesia has 89 observations (from January 1996) and China has 121 observations (from May 1993). Many real estate stock indexes, including those of the UK, Singapore, Hong Kong, Malaysia, Thailand and Indonesia, are capitalization weighted indexes of all real estate stocks of their respective broad market indexes. ${ }^{4}$

\footnotetext{
${ }^{4}$ The Korean and Taiwan Construction Indexes are broadly the equivalent of their respective real estate stock indexes. 
Table 1: Real Estate Index Description

\begin{tabular}{|c|c|}
\hline China & $\begin{array}{l}\text { Shanghai Stock Exchange Property index is a capitalization-weighted index of stocks that } \\
\text { track the performance of the listed real estate listed on the Shanghai Stock Exchange. It } \\
\text { consists of } 16 \text { members and its total market capitalization was } 80.86 \text { billion renminbi (USD } \\
9.77 \text { b) as at } 12 / 09 / 02 \text {. }\end{array}$ \\
\hline Hong Kong & $\begin{array}{l}\text { Hang Seng Property Index is a capitalization-weighted index of all the stocks designed to } \\
\text { measure the performance of the property sector at the Hong Kong Stock Exchange. The } \\
\text { index consists of } 6 \text { members and its total market capitalization was HK\$315.8 billion (USD } \\
40.49 \mathrm{~b} \text { ) as at } 11 / 07 / 03 \text {. }\end{array}$ \\
\hline Indonesia & $\begin{array}{l}\text { Jakarta Construction, Property and RE Index is a capitalization-weighted index of all stocks } \\
\text { involved in construction, property and real estate of Jakarta Composite Index. The index } \\
\text { was developed with base value of } 100 \text { as of } 28 / 12 / 95 \text {. It consists of } 32 \text { members and its total } \\
\text { capitalization was } 4.83 \text { trillion rupiah (USD } 0.59 \mathrm{~b} \text { ) as at } 11 / 07 / 03 \text {. }\end{array}$ \\
\hline Japan & $\begin{array}{l}\text { Topix Real Estate Index is a capitalization-weighted index designed to measure the } \\
\text { performance of the real estate sector of the Topix Index. The index was developed with a } \\
\text { base value of } 100 \text { as of } 04 / 02 / 68 \text {. It consists of } 34 \text { members with a total market } \\
\text { capitalization of } \$ 2.98 \text { trillion yen (USD } 25.29 \mathrm{~b} \text { ) as at } 11 / 07 / 03 \text {. }\end{array}$ \\
\hline Korea & $\begin{array}{l}\text { Korea Stock Exchange Construction Index is a capitalization-weighted index of all stocks } \\
\text { in the construction industry group of the Korean Stock Exchanges. }\end{array}$ \\
\hline Malaysia & $\begin{array}{l}\text { Kuala Lumpur Stock Exchange Property Index is a capitalization-weighted index of all } \\
\text { stocks in the EMAS index involved in the property sector. It consists of } 84 \text { members with a } \\
\text { total market capitalization of } 25.33 \text { billion ringgit (USD } 6.67 \mathrm{~b} \text { ) as at } 11 / 07 / 03 \text {. }\end{array}$ \\
\hline Philippines & $\begin{array}{l}\text { Philippines Stock Exchange Property Index is a market capitalization-weighted index of } \\
\text { companies representative of the property sector listed on the Philippines Stock Exchange. It } \\
\text { consists of } 10 \text { members with a total market capitalization of } \$ 135 \text { billion pesos (USD } \\
2.60 \mathrm{~b} \text { ) as at } 12 / 09 / 02 \text {. }\end{array}$ \\
\hline Singapore & $\begin{array}{l}\text { Singapore Property Equities Index is a capitalization-weighted index of all the stocks traded } \\
\text { on the Stock Exchange of Singapore's property sector. The index was developed with base } \\
\text { value of } 1000 \text { as of } 03 / 01 / 97 \text {. It consists of } 21 \text { members with a total market capitalization of } \\
\text { S } \$ 16.65 \text { billion (USD } 9.49 \text { b) as at } 11 / 07 / 03 \text {. }\end{array}$ \\
\hline Taiwan & $\begin{array}{l}\text { TWSE Construction Index is a capitalization-weighted index that measures the performance } \\
\text { of the construction sector of the TWSE Index. It consists of } 27 \text { members with a total market } \\
\text { capitalization of T\$77.83 billion (USD } 2.26 \mathrm{~b} \text { ) as at } 11 / 07 / 03 \text {. }\end{array}$ \\
\hline Thailand & $\begin{array}{l}\text { SET Property Development Index is a capitalization-weighted index of all stocks of the } \\
\text { SET Index that are involved in the property sector. It consists of } 28 \text { members with a total } \\
\text { market capitalization of } 181.2 \text { billion baht (USD } 4.35 \mathrm{~b} \text { ) as at } 11 / 07 / 03 \text {. }\end{array}$ \\
\hline US & $\begin{array}{l}\text { The NAREIT Index includes all REITs trading on the New York Stock Exchange, the } \\
\text { NASDAQ National Market System and the American Stock Exchange. The index provides } \\
\text { a standard with which to measure the REIT industry's growth and performance. It consists } \\
\text { of } 50 \text { members with a total market capitalization of US } \$ 135.0 \text { billion as at } 30 / 06 / 03 \text {. }\end{array}$ \\
\hline UK & $\begin{array}{l}\text { FTSE } 350 \text { Real Estate Index is a capitalization-weighted index of stocks designed to } \\
\text { measure the performance of the real estate sector of the FTSE } 350 \text { Index. The index was } \\
\text { developed with a base value of } 1000 \text { as of } 31 / 12 / 85 \text {. It consists of } 18 \text { members and its total } \\
\text { market capitalization was } 16.96 \text { billion pounds (USD } 27.72 \mathrm{~b} \text { ) as at } 11 / 07 / 03 \text {. }\end{array}$ \\
\hline
\end{tabular}

Notes: These are listed (exchange based) real estate indexes. Except for the USA, they are real estate stock indexes under the respective stock exchanges.

Source: Datastream / various stock exchanges 
Table 2: Stock Market Index Description

\begin{tabular}{|c|c|}
\hline China & $\begin{array}{l}\text { The Shanghai Stock Price Index is a capitalization-weighted index. The index tracks the daily price } \\
\text { performance of all A-shares and B-shares listed on the Shanghai Stock Exchange. The index was } \\
\text { developed on } 19 / 12 / 90 \text { with a base value of } 100 \text {. It consists of } 788 \text { members and its total market } \\
\text { capitalization was } 2.88 \text { trillion renminbi (USD } 347.95 \text { b) as at } 18 / 07 / 03 \text {. }\end{array}$ \\
\hline Hong Kong & $\begin{array}{l}\text { The Hang Seng Index is a capitalization-weighted index of } 33 \text { companies that represent } \\
\text { approximately } 70 \% \text { of the total market capitalization of the stock Exchange of Hong Kong. The } \\
\text { components of the index are subdivided into } 4 \text { sub-indexes: Commerce \& Industry, Finance, } \\
\text { Utilities and Properties. . The index was developed with a base value of } 100 \text { as of } 31 / 07 / 64 \text {. The } \\
\text { index consists of } 33 \text { members and its total market capitalization was HK } \$ 3.09 \text { trillion (USD } \\
396.19 \mathrm{~b} \text { ) as at } 18 / 07 / 03 \text {. }\end{array}$ \\
\hline Indonesia & $\begin{array}{l}\text { The Jakarta Stock Price Index is a modified capitalization-weighted index of all stocks listed on the } \\
\text { regular board of the Jakarta Stock Exchange. The index has a base date as of 10/08/82. It consists } \\
\text { of } 336 \text { members and its total capitalization was } 359.7 \text { trillion rupiah (USD } 43.18 \mathrm{~b} \text { ) as at 18/07/03. }\end{array}$ \\
\hline Japan & $\begin{array}{l}\text { The Topix, also known as the Tokyo Price Index, is a capitalization-weighted index of all the } \\
\text { companies listed on the First Section of the Tokyo Stock Exchange. The index is supplemented by } \\
\text { the sub-indices of the } 33 \text { industry sectors and developed with a base value of } 100 \text { as of } 04 / 01 / 68 \text {. It } \\
\text { consists of } 1522 \text { members with a total market capitalization of } \$ 275.2 \text { trillion yen (USD } 2.31 \text { trillion) } \\
\text { as at } 18 / 07 / 03 \text {. }\end{array}$ \\
\hline Korea & $\begin{array}{l}\text { The Korea Stock Price Index is a capitalization-weighted index of all common shares of the Korean } \\
\text { Stock Exchanges. The index was developed with a base value of } 100 \text { as of } 04 / 01 / 80 \text {. It consists of } \\
681 \text { members with a total market capitalization of } 282.1 \text { trillion won (USD } 239.31 \text { b) as at } 18 / 07 / 03 \text {. }\end{array}$ \\
\hline Malaysia & $\begin{array}{l}\text { The Kuala Lumpur Stock Exchange Composite Index is a broad-based capitalization-weighted } \\
\text { index of } 100 \text { stocks designed to measure the performance of the Kuala Lumpur Stock Exchange. } \\
\text { The index has a base value of } 95.83 \text { as of } 03 / 01 / 77 \text {. It consists of } 100 \text { members with a total market } \\
\text { capitalization of } 344.9 \text { billion ringgit (USD } 90.76 \text { b) as at } 18 / 07 / 03 \text {. }\end{array}$ \\
\hline Philippines & $\begin{array}{l}\text { The Philippines Stock Exchange Composite Index is a capitalization-weighted index composed of } \\
\text { stocks representative of the Commercial, Industrial, Property, Mining and Oil sectors of the } \\
\text { Philippines Stock Exchange. The index has a base value of } 2922.21 \text { as of } 30 / 09 / 04 \text {. It consists of } 33 \\
\text { members with a total market capitalization of } 901.3 \text { billion pesos (USD } 16.78 \text { b) as at } 18 / 07 / 03 \text {. }\end{array}$ \\
\hline Singapore & $\begin{array}{l}\text { The Singapore All Equities Index is a capitalization-weighted index of stocks traded on Singapore's } \\
\text { mainboard. The index is designed to provide a measure of the overall price movement in the stock } \\
\text { market. The index was developed with a base value of } 100 \text { as of } 02 / 01 / 75 \text {. It consists of } 321 \\
\text { members with a total market capitalization of } S \$ 209.0 \text { billion (USD } 118.53 \mathrm{~b} \text { ) as at } 18 / 07 / 03 \text {. }\end{array}$ \\
\hline Taiwan & $\begin{array}{l}\text { The TWSE Index is a capitalization-weighted index of all listed common shares traded on the } \\
\text { Taiwan Stock Exchange. The index was based in } 1966 \text {. It consists of } 617 \text { members with a total } \\
\text { market capitalization of T } \$ 10.8 \text { trillion (USD } 313.32 \mathrm{~b} \text { ) as at } 18 / 07 / 03 \text {. }\end{array}$ \\
\hline Thailand & $\begin{array}{l}\text { The Bangkok SET Index is a capitalization-weighted index of all the stocks traded on the Stock } \\
\text { Exchange of Thailand. The index was developed with a base value of } 100 \text { as of } 30 / 04 / 75 \text {. It consists } \\
\text { of } 352 \text { members with a total market capitalization of } 2.61 \text { trillion baht (USD } 62.51 \mathrm{~b} \text { ) as at } 18 / 07 / 03 \text {. }\end{array}$ \\
\hline US & $\begin{array}{l}\text { Standard \& Poor's } 500 \text { Index is a capitalization-weighted index of } 500 \text { stocks. The index is designed } \\
\text { to measure performance of the broad domestic economy though changes in the aggregate market } \\
\text { value of } 500 \text { stocks representing all major industries. The index was developed with a base value of } \\
10 \text { for the } 1941-43 \text { base period. It consists of } 500 \text { members and its total market capitalization was } \\
\text { US } \$ 9.05 \text { trillion as at } 18 / 07 / 03 \text {. }\end{array}$ \\
\hline UK & $\begin{array}{l}\text { The FTSE } 350 \text { is a capitalization-weighted index comprising of all the components of the FTSE } 100 \\
\text { and the FTSE 250. The index represents approximately } 90 \% \text { of the UK equity market by } \\
\text { capitalization. The starting base value was set at the FTSE ALL Share closing value of } 682.94 \text { as of } \\
31 / 12 / 85 \text {. It consists of } 353 \text { members and its total market capitalization was } 1.16 \text { trillion pounds } \\
\text { (USD } 1.85 \text { trillion) as at } 18 / 07 / 03 \text {. }\end{array}$ \\
\hline
\end{tabular}

Source: Datastream /various stock exchanges 


\section{RETURN AND RISK}

Table 3 contains the summation of the monthly analyzed dollar returns for the 12 markets for the time period 1990-2003. These returns are shown for each year. The range of real estate security returns is between $-233.34 \%$ (Thailand: 1997) and $105.58 \%$ (Malaysia: 1993). The star performer is Hong Kong whose geometric mean annual return over this period was $5.86 \%$. Additionally, Table 3 also provides the number of times that an individual listed real estate market return beats the respective market return. In 6 of the 10 Asian markets with complete 14-year annual return data ${ }^{5}$, only Hong Kong's and Singapore's real estate security index returns beat the market index in at least $50 \%$ of the times ( 8 for HK and 7 for Singapore). These results compare favorably with similar results for the USA, UK and Japan where 6 times each is reported. Overall, the market in general performed better than real estate over this period.

Table 4 contains the following data for the monthly real estate and market indexes: the geometric mean of monthly returns in US dollar; the geometric mean of monthly returns in local currency and the standard deviation of monthly returns in US dollar. As can be seen, the difference between local currency returns and dollar returns is quite substantial in many cases. The local returns of both real estate and market indexes for Malaysia, Philippines, Thailand, Indonesia, China, Korea and Taiwan are all higher than the dollar returns, with some indexes differing by a large margin. For example, the local return of China real estate index is double its dollar return; and Malaysia, Philippines and Indonesia's positive local returns for the market indexes become negative after translating into dollar terms. This reflects the currency devaluation in most Asian countries, possibly contributed largely by the Asian financial crisis. Hong Kong's local and dollar returns are of the same magnitude, reflecting its pegged exchange rate policy. Finally, Singapore and Japan have a higher dollar return than local return for both indexes.

\footnotetext{
${ }^{5}$ The 6 Asian markets with complete real estate and market returns data are: Singapore, Hong Kong, Malaysia, Thailand, Korea and Japan. Taiwan's market return data are available from September 1994 onwards although it has full 14-year real estate return data.
} 
Table 3: Real Estate Stock Index (PI): annual return (\%): 1990-2003

\begin{tabular}{|c|c|c|c|c|c|c|c|c|c|c|c|c|}
\hline & Singapore & Hong Kong & Malaysia & Philippines & Thailand & Indonesia & China & Korea & Taiwan & Japan & USA & UK \\
\hline 1990 & -37.83 & 7.09 & -29.10 & & -0.12 & & & -33.90 & -102.18 & -68.61 & -33.55 & -2.88 \\
\hline 1991 & 25.09 & 38.91 & -4.71 & & 41.31 & & & -45.95 & 46.36 & 13.62 & 20.78 & -20.50 \\
\hline 1992 & -8.57 & 16.90 & 6.42 & & 21.09 & & & 26.66 & -31.55 & -43.75 & 2.83 & -38.90 \\
\hline 1993 & 75.80 & 97.78 & 105.58 & & 67.27 & & 20.82 & 19.29 & 20.38 & 18.43 & 10.05 & 55.85 \\
\hline 1994 & 11.26 & -49.87 & -22.16 & & -62.30 & & -12.80 & 27.44 & 11.67 & 14.95 & -6.62 & -18.58 \\
\hline 1995 & 10.04 & 26.25 & -19.06 & -0.74 & -23.16 & & -19.09 & -31.02 & -34.09 & 8.36 & 8.73 & 0.70 \\
\hline 1996 & 5.29 & 40.58 & 19.33 & 28.43 & -61.45 & 28.22 & 52.96 & -45.20 & 27.22 & -20.63 & 23.52 & 30.79 \\
\hline 1997 & -76.12 & -57.69 & -163.75 & -107.41 & -233.34 & -154.59 & 3.55 & -176.36 & -0.29 & -16.58 & 11.20 & 15.28 \\
\hline 1998 & 22.21 & -4.28 & -30.63 & -6.20 & -24.48 & -146.63 & -18.27 & 60.61 & -56.92 & -18.10 & -27.21 & -22.89 \\
\hline 1999 & 35.07 & 33.00 & 62.99 & -0.72 & -6.67 & 98.08 & 15.08 & -20.07 & -58.68 & 2.90 & -15.15 & 1.81 \\
\hline 2000 & -23.43 & -8.08 & -48.43 & -63.96 & -88.24 & -98.08 & 29.75 & -109.86 & -74.00 & 12.20 & 14.77 & 8.24 \\
\hline 2001 & -33.09 & -16.57 & -5.34 & -4.43 & 65.06 & 0.00 & -14.03 & 51.08 & -14.25 & -29.45 & 6.81 & -12.15 \\
\hline 2002 & -25.84 & -33.71 & -10.30 & -21.75 & 56.83 & 0.00 & -23.79 & -22.31 & 3.07 & -9.01 & -2.18 & 5.38 \\
\hline 2003 & 13.37 & -8.25 & 9.98 & 24.69 & 20.42 & 28.77 & -4.16 & 22.31 & 11.95 & -1.75 & 10.44 & 6.40 \\
\hline \begin{tabular}{|l|}
$\begin{array}{l}\text { Mean } \\
\text { (geometric) }\end{array}$ \\
\end{tabular} & -0.48 & 5.86 & -9.23 & -15.33 & -16.27 & -30.53 & 2.73 & -19.81 & -17.95 & -9.82 & 1.74 & 0.61 \\
\hline $\begin{array}{l}\text { Number of } \\
\text { years } \\
\text { PI beats MI }\end{array}$ & 7 & 8 & 3 & 4 & 5 & 3 & 3 & 5 & $4^{1}$ & 6 & 6 & 6 \\
\hline
\end{tabular}

$\mathrm{PI}$ - denotes property stock index

MI - denotes market index

${ }^{1}$ The comparison does not include 1990-1994. This is because the MI series for Taiwan is only available from September 1994 onwards.

2 The beginning data month for Philippines, Indonesia and China are October 1994, January 1996 and May 1993 respectively 
Table 4: Summary Statistics for Real Estate and Market Indexes Monthly Returns: Jan 1990- June 2003 *

\begin{tabular}{|c|c|c|c|c|c|c|c|c|c|}
\hline $\begin{array}{l}\text { Country / } \\
\text { Index }\end{array}$ & $\begin{array}{c}\text { Mean } \\
\text { Return } \\
(\%)\end{array}$ & $\begin{array}{c}\text { Local } \\
\text { Return } \\
(\%)\end{array}$ & $\begin{array}{c}\text { Standard } \\
\text { Deviation } \\
(\%)\end{array}$ & $\begin{array}{l}\text { Max } \\
(\%) \\
\end{array}$ & $\begin{array}{l}\text { Min } \\
(\%) \\
\end{array}$ & Skewness & Kurtosis & $\begin{array}{c}\text { Jarque- } \\
\text { Bera }\end{array}$ & $\begin{array}{l}\text { Proba } \\
\text { bility }\end{array}$ \\
\hline \multicolumn{10}{|l|}{ Singapore } \\
\hline PI & -0.04 & -0.09 & 12.38 & 51.56 & -41.96 & 0.360 & 7.474 & 138.60 & 0.000 \\
\hline MI & 0.05 & 0.01 & 7.34 & 25.22 & -20.73 & -0.114 & 4.669 & 19.16 & 0.000 \\
\hline \multicolumn{10}{|l|}{ Hong Kong } \\
\hline PI & 0.51 & 0.51 & 11.28 & 45.82 & -45.98 & 0.182 & 6.111 & 66.21 & 0.000 \\
\hline MI & 0.75 & 0.75 & 8.18 & 26.74 & -34.71 & -0.105 & 5.140 & 31.21 & 0.000 \\
\hline \multicolumn{10}{|l|}{ Malaysia } \\
\hline PI & -0.80 & -0.59 & 12.96 & 52.59 & -38.26 & 0.217 & 4.996 & 28.15 & 0.000 \\
\hline MI & -0.08 & 0.13 & 10.08 & 39.81 & -33.10 & 0.020 & 5.606 & 45.85 & 0.000 \\
\hline \multicolumn{10}{|l|}{ Philippines } \\
\hline PI & -1.47 & -0.74 & 13.18 & 59.59 & -38.39 & 0.776 & 7.262 & 89.13 & 0.000 \\
\hline MI & -0.50 & 0.06 & 10.78 & 41.26 & -33.85 & 0.032 & 4.968 & 26.17 & 0.000 \\
\hline \multicolumn{10}{|l|}{ Thailand } \\
\hline PI & -1.41 & -1.09 & 18.75 & 68.45 & -108.46 & -0.751 & 9.737 & 321.58 & 0.000 \\
\hline MI & -0.71 & -0.40 & 11.68 & 34.00 & -35.16 & -0.148 & 3.848 & 5.45 & 0.066 \\
\hline \multicolumn{10}{|l|}{ Indonesia } \\
\hline PI & -2.74 & -1.40 & 26.93 & 69.31 & -95.55 & -0.097 & 4.849 & 12.82 & 0.002 \\
\hline MI & -0.80 & 0.15 & 13.13 & 43.08 & -50.24 & -0.470 & 5.527 & 49.08 & 0.000 \\
\hline \multicolumn{10}{|l|}{ China } \\
\hline PI & 0.25 & 0.55 & 14.53 & 104.88 & -38.68 & 3.015 & 24.282 & 2466.83 & 0.000 \\
\hline MI & 1.32 & 1.64 & 16.82 & 101.49 & -48.48 & 2.033 & 15.004 & 997.27 & 0.000 \\
\hline \multicolumn{10}{|l|}{ Korea } \\
\hline PI & -1.71 & -1.36 & 14.52 & 45.20 & -60.61 & -0.724 & 6.568 & 100.08 & 0.000 \\
\hline MI & -0.54 & -0.19 & 11.92 & 51.99 & -46.43 & 0.141 & 6.302 & 74.11 & 0.000 \\
\hline \multicolumn{10}{|l|}{ Taiwan } \\
\hline PI & -1.55 & -1.38 & 13.41 & 36.57 & -50.16 & -0.131 & 4.411 & 13.91 & 0.001 \\
\hline MI & -0.69 & -0.42 & 8.67 & 20.89 & -25.44 & -0.0930 & 2.733 & 0.47 & 0.791 \\
\hline \multicolumn{10}{|l|}{ Japan } \\
\hline PI & -0.85 & -0.96 & 9.62 & 28.56 & -34.95 & 0.063 & 3.687 & 3.30 & 0.192 \\
\hline MI & -0.61 & -0.72 & 7.11 & 22.95 & -19.68 & 0.264 & 3.344 & 2.69 & 0.261 \\
\hline \multicolumn{10}{|l|}{ USA } \\
\hline PI & 0.15 & 0.15 & 3.48 & 9.08 & -11.61 & -0.046 & 3.242 & 0.45 & 0.798 \\
\hline MI & 0.63 & 0.63 & 4.40 & 10.58 & -15.76 & -0.585 & 3.674 & 12.30 & 0.002 \\
\hline \multicolumn{10}{|l|}{ United } \\
\hline Kingdom & 0.05 & 0.04 & 5.93 & 14.42 & -15.73 & -0.257 & 2.836 & 1.97 & 0.373 \\
\hline PI & 0.33 & 0.31 & 4.54 & 13.14 & -11.09 & -0.037 & 2.814 & 0.27 & 0.873 \\
\hline MI & & & & & & & & & \\
\hline
\end{tabular}

Comparing the performance of real estate and market indexes, it is interesting to note that in all ten markets, both the geometric monthly dollar returns and local returns of market indexes are higher than those of real estate indexes. Again, these results imply that when

Pacific Rim Property Research Journal, Vol 12, No 3 
risk is ignored and return only is considered, the market indexes outperform the respective listed real estate indexes. This also holds true for the US and UK markets. Lastly, all the Asian real estate index returns are negative, except for Hong Kong (0.51\%) and China $(0.25 \%)$. The US and the UK markets report positive real estate index returns of $0.15 \%$ and $0.05 \%$ respectively.

The ranges of return volatility, measured by the standard deviation of returns, are between $3.48 \%$ (USA), 5.93\% (UK), 9.52\% (Japan) and 26.93\% (Indonesia) for the 12 listed real estate indexes. On the other hand, the corresponding range is between $4.40 \%$ (USA) and $16.82 \%$ (China) for the 12 market indexes. In all markets except for China and the USA, real estate indexes have a higher return volatility than market indexes. Specifically for Indonesia, its unconditional real estate return volatility is more than double that of the market index. On the contrary, the NAREIT index has the lowest monthly return volatility (3.48\%) followed by the UK FTSE real estate index (5.93\%). This does not bode well for Asian real estate investments. However, the influence of the Asian financial crisis should again be taken into consideration.

Another observation is that the listed real estate indexes in Hong Kong and China are the only two Asian markets that report positive monthly returns, that probably reflect the phenomenal development of China over the past decade relative to other Asian countries. The other eight Asian listed real estate markets underperformed their USA and UK counterparts both in risk and return measures. Notably, the NAREIT index is far less risky than any of the 10 Asian real estate indexes (3.48\% versus Japan's 9.62\%). Compared to the S \& P 500 index, the NAREIT index has lower average monthly return and also a smaller return volatility over the sample period. Finally, our real estate index return results are different from those of Bekaert et al. (1998) who find that returns of the emerging markets are higher than the world market portfolio in 10 out of 17 emerging markets. In our case, eight of ten Asian listed real estate markets fail to outperform the NAREIT index when return only is considered. One possible explanation for this return underperformance was that almost all the Asian real estate markets were badly affected by the 1997 Asian financial crisis and economic downturn; evidenced by negative returns especially over the period 1997-2000. Our sub-period results that follow will shed additional light on this issue.

Tables 5 and 6 contain the statistics for the listed real estate index and market index performance indicators for January 1990 - June 1997( $1^{\text {st }}$ sub-period) and July 1997 - June 2003 ( $2^{\text {nd }}$ sub-period $)$ respectively. The full period is divided in this manner to compare performance before and following the Asian financial crisis which starts on 2 July 1997. The Asian financial crisis has resulted in the rise of observed volatility of the financial and real estate markets in the region and around the world. It should be noted that data for the first sub-period pertaining to Philippines, Indonesia and China are incomplete. 
Table 5: Summary Statistics for Real Estate and Market Indexes’ Monthly Returns: Jan 1990- June 1997*

\begin{tabular}{|c|c|c|c|c|c|c|c|}
\hline $\begin{array}{l}\text { Country } \\
\text { Index } * *\end{array}$ & $\begin{array}{c}\text { Mean } \\
\text { Return } \\
(\%)\end{array}$ & $\begin{array}{c}\text { Local } \\
\text { Return } \\
(\%)\end{array}$ & $\begin{array}{c}\text { Standard } \\
\text { Deviation } \\
(\%)\end{array}$ & Skewness & Kurtosis & $\begin{array}{c}\text { Jarque- } \\
\text { Bera }\end{array}$ & Probability \\
\hline \multicolumn{8}{|l|}{ Singapore } \\
\hline PI & 0.85 & 0.54 & 7.52 & -0.217 & 2.945 & 0.72 & 0.698 \\
\hline MI & 0.58 & 0.26 & 5.42 & -0.459 & 4.805 & 15.38 & 0.000 \\
\hline \multicolumn{8}{|l|}{ Hong Kong } \\
\hline PI & 1.91 & 1.91 & 8.81 & 0.731 & 4.760 & 19.62 & 0.000 \\
\hline MI & 1.87 & 1.86 & 6.83 & 0.398 & 4.405 & 9.78 & 0.008 \\
\hline \multicolumn{8}{|l|}{ Malaysia } \\
\hline PI & 0.44 & 0.36 & 10.48 & -0.275 & 2.990 & 1.14 & 0.567 \\
\hline MI & 0.80 & 0.72 & 6.69 & -0.330 & 3.697 & 3.45 & 0.178 \\
\hline \multicolumn{8}{|l|}{ Philippines } \\
\hline PI & 0.59 & 0.77 & 8.20 & -0.909 & 3.782 & 5.22 & 0.073 \\
\hline MI & 0.80 & 1.04 & 9.92 & -0.320 & 4.933 & 15.54 & 0.000 \\
\hline \multicolumn{8}{|l|}{ Thailand } \\
\hline PI & -1.11 & -1.08 & 13.83 & 0.460 & 3.746 & 5.26 & 0.072 \\
\hline MI & -0.60 & -0.57 & 9.28 & -0.042 & 4.141 & 4.91 & 0.086 \\
\hline \multicolumn{8}{|l|}{ Indonesia } \\
\hline PI & 2.47 & 2.83 & 4.64 & 0.357 & 2.654 & 0.45 & 0.800 \\
\hline MI & 0.33 & 0.66 & 7.71 & -0.011 & 2.980 & 0.00 & 0.998 \\
\hline \multicolumn{8}{|l|}{ China } \\
\hline PI & 1.57 & 2.33 & 20.78 & 2.390 & 13.928 & 290.47 & 0.000 \\
\hline MI & 2.33 & 2.94 & 22.47 & 1.518 & 8.889 & 140.81 & 0.000 \\
\hline \multicolumn{8}{|l|}{ Korea } \\
\hline PI & -1.02 & -0.71 & 8.27 & 0.008 & 2.835 & 0.10 & 0.949 \\
\hline MI & -0.53 & -0.22 & 7.23 & 0.229 & 3.265 & 1.05 & 0.591 \\
\hline \multicolumn{8}{|l|}{ Taiwan } \\
\hline PI & -0.42 & -0.35 & 12.94 & -0.831 & 6.497 & 56.20 & 0.000 \\
\hline MI & 0.51 & 0.68 & 7.13 & 0.042 & 2.418 & 0.49 & 0.783 \\
\hline \multicolumn{8}{|l|}{ Japan } \\
\hline PI & -0.56 & -0.82 & 10.12 & -0.227 & 3.775 & 3.03 & 0.220 \\
\hline MI & -0.43 & -0.69 & 7.77 & 0.200 & 3.518 & 1.61 & 0.448 \\
\hline \multicolumn{8}{|l|}{ USA } \\
\hline PI & 0.32 & 0.32 & 3.25 & 0.059 & 3.009 & 0.05 & 0.974 \\
\hline MI & 1.02 & 1.02 & 3.41 & -0.295 & 3.796 & 3.68 & 0.159 \\
\hline \multicolumn{8}{|l|}{ United } \\
\hline Kingdom & 0.15 & 0.12 & 6.34 & -0.471 & 2.664 & 3.75 & 0.153 \\
\hline PI & 0.75 & 0.71 & 4.49 & 0.059 & 3.036 & 0.06 & 0.972 \\
\hline MI & & & & & & & \\
\hline
\end{tabular}

${ }^{*}$ The beginning data month for Philippines, Indonesia and China are October 1994, January 1996 and May 1993 respectively.

${ }^{* *}$ All data are based on US $\$$ except for local return which is based on local currency. PI - real estate index; MI - market index 
Table 6: Summary Statistics for Real Estate and Market Indexes’ Monthly Returns: July 1997- June 2003

\begin{tabular}{|c|c|c|c|c|c|c|c|}
\hline $\begin{array}{l}\text { Country } \\
\text { Index }\end{array}$ & $\begin{array}{c}\text { Mean } \\
\text { Return } \\
(\%)\end{array}$ & $\begin{array}{c}\text { Local } \\
\text { Return } \\
(\%)\end{array}$ & $\begin{array}{c}\text { Standard } \\
\text { Deviation } \\
(\%)\end{array}$ & Skewness & Kurtosis & $\begin{array}{c}\text { Jarque- } \\
\text { Bera }\end{array}$ & Probability \\
\hline \multicolumn{8}{|l|}{ Singapore } \\
\hline PI & -1.16 & -0.87 & 16.57 & 0.529 & 5.287 & 19.05 & 0.000 \\
\hline MI & -0.60 & -0.31 & 9.20 & 0.126 & 3.622 & 1.35 & 0.509 \\
\hline \multicolumn{8}{|l|}{ Hong Kong } \\
\hline PI & -1.25 & -1.24 & 13.62 & 0.214 & 5.393 & 17.73 & 0.000 \\
\hline MI & -0.65 & -0.64 & 9.47 & -0.125 & 4.686 & 8.71 & 0.013 \\
\hline \multicolumn{8}{|l|}{ Malaysia } \\
\hline PI & -2.34 & -1.77 & 15.45 & 0.562 & 5.034 & 16.20 & 0.000 \\
\hline MI & -1.18 & -0.61 & 13.13 & 0.263 & 4.201 & 5.16 & 0.076 \\
\hline \multicolumn{8}{|l|}{ Philippines } \\
\hline PI & -2.39 & -1.41 & 14.83 & 0.988 & 6.694 & 52.65 & 0.000 \\
\hline MI & -2.14 & -1.16 & 11.63 & 0.423 & 5.258 & 17.43 & 0.000 \\
\hline \multicolumn{8}{|l|}{ Thailand } \\
\hline PI & -1.78 & -1.11 & 23.61 & -0.941 & 8.233 & 92.79 & 0.000 \\
\hline MI & -0.86 & -0.94 & 14.20 & -0.155 & 3.076 & 0.31 & 0.858 \\
\hline \multicolumn{8}{|l|}{ Indonesia } \\
\hline PI & -3.98 & -2.40 & 29.76 & 0.031 & 4.031 & 3.20 & 0.202 \\
\hline MI & -2.20 & -0.50 & 17.68 & -0.242 & 3.582 & 1.72 & 0.423 \\
\hline \multicolumn{8}{|l|}{ China } \\
\hline PI & -0.65 & -0.66 & 7.93 & 0.453 & 4.000 & 5.46 & 0.065 \\
\hline MI & 0.24 & 0.24 & 6.82 & 0.857 & 5.480 & 27.26 & 0.000 \\
\hline \multicolumn{8}{|l|}{ Korea } \\
\hline PI & -2.58 & -2.17 & 19.77 & -0.544 & 4.146 & 7.493 & 0.024 \\
\hline MI & -0.56 & -0.15 & 16.02 & 0.109 & 4.243 & 4.775 & 0.092 \\
\hline \multicolumn{8}{|l|}{ Taiwan } \\
\hline PI & -2.97 & -2.66 & 13.93 & 0.612 & 2.986 & 4.494 & 0.106 \\
\hline MI & -1.25 & -0.94 & 9.30 & -0.044 & 2.616 & 0.465 & 0.793 \\
\hline \multicolumn{8}{|l|}{ Japan } \\
\hline PI & -1.21 & -1.14 & 9.03 & 0.544 & 3.517 & 4.35 & 0.114 \\
\hline MI & -0.82 & -0.75 & 6.25 & 0.348 & 2.256 & 3.12 & 0.210 \\
\hline \multicolumn{8}{|l|}{ USA } \\
\hline PI & -0.05 & -0.05 & 3.77 & -0.089 & 3.261 & 0.298 & 0.798 \\
\hline MI & 0.13 & 0.13 & 5.37 & -0.471 & 2.788 & 2.799 & 0.247 \\
\hline \multicolumn{8}{|l|}{ United } \\
\hline Kingdom & -0.07 & -0.06 & 5.42 & 0.153 & 3.104 & 0.31 & 0.854 \\
\hline PI & -0.197 & -0.18 & 4.58 & -0.140 & 2.453 & 1.13 & 0.568 \\
\hline
\end{tabular}

All data are based on US\$ except for local return which is based on local currency.

$\mathrm{PI}$ - denotes real estate index

MI - denotes market index 
Several observations can be drawn from the data. First, the local returns of both real estate and market indexes for Singapore, Malaysia and Japan were less than the dollar returns from Jan 1990 to June 1997. However, this was reversed during the July1997 to end December 2003 time period, reflecting the depreciation of the Asian currencies following the financial crisis. Second, the real estate indexes for Singapore and Hong Kong outperformed their respective market indexes over 1990-1997, but this was again reversed for the 1997-2003 time period, reflecting the real estate slump that had affected these two markets. Third, six Asian markets outperformed the US REITs and UK real estate index with higher positive mean monthly returns ranging between $0.44 \%$ and $2.47 \%$ over the 1990-1997 time period; however, all the 10 Asian markets experienced negative monthly returns of between $-0.65 \%$ (China) and $-3.98 \%$ (Indonesia) from 1997 to 2003, reflecting the adverse effect of regional financial crisis and economic slowdown on the listed real estate markets. Fourth, except for China and Japan, the remaining eight real estate indexes experienced much higher volatility from 1997 to 2003. Our results are consistent with those of Kallburg et al. (2002) who found some evidence of a reduction in real estate returns and an increase in real estate volatility in several Asian markets following the eruption of Asian financial crisis. Finally, the NAREIT index registered a small increase in return volatility while the UK real estate index was less volatile over the 1997-2003 time period.

\section{NORMALITY, SKEWNESS AND KURTOSIS}

An examination of the histograms for the real estate and market return series reveals that the returns for most indexes deviate from the normally distributed return curves with identical mean and variance parameters. Figure 1 plots the normality graphs for the 12 real estate indexes. Some real estate indexes seem to have produced an unusually large number of extreme returns. In particular, the Indonesian real estate index exhibits the most extreme distribution pattern, with no resemblance of normality. In addition, several indexes are skewed to the right due to the presence of positive outliers, such as the real estate and market indexes of China and Philippines. Another observation is that many indexes contain extreme peaks, such as the real estate indexes of Hong Kong, Malaysia, Indonesia, Korea, and the market indexes of Malaysia, China and Korea. 
Figure 1: Normality Graphs

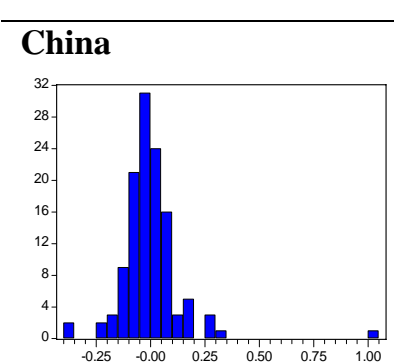

Hong Kong

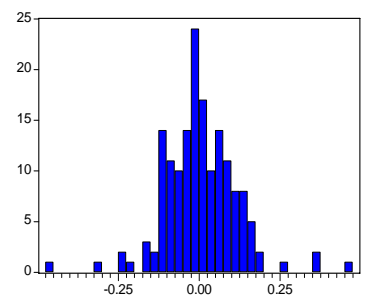

Indonesia

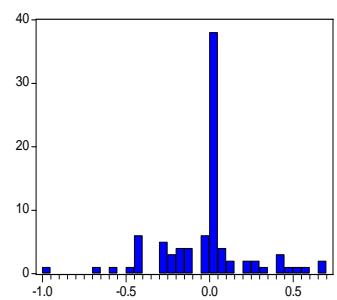

Japan

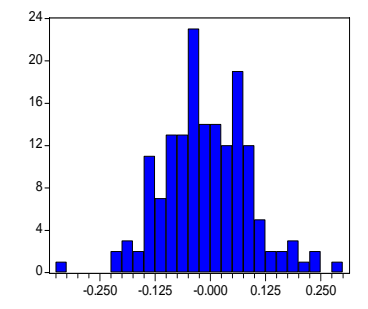

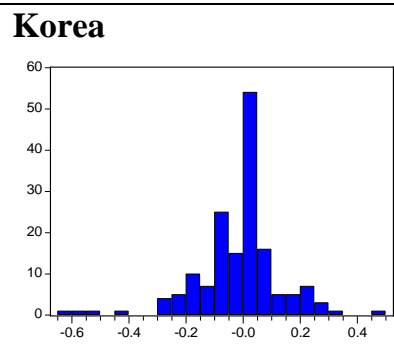

Malaysia

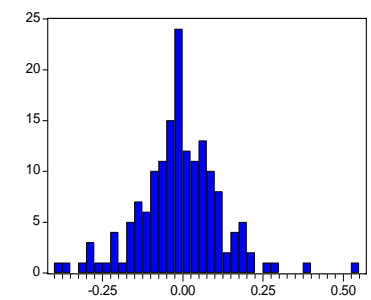

Philippines

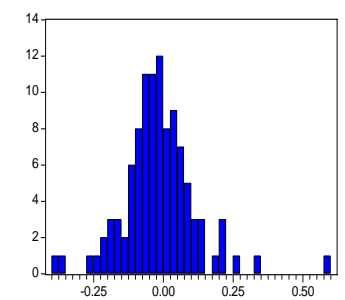

Singapore

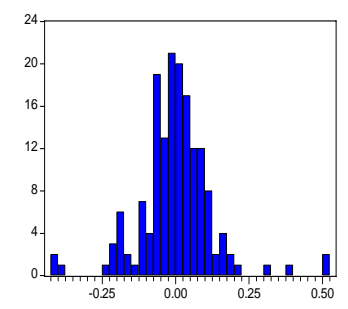

\section{Taiwan}

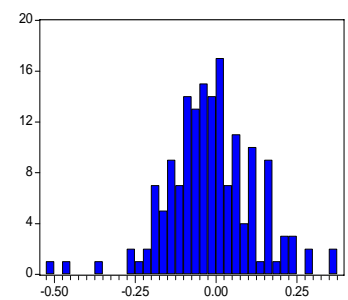

Thailand

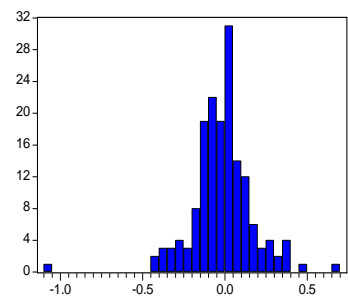

USA

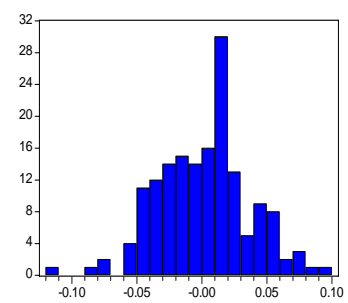

UK

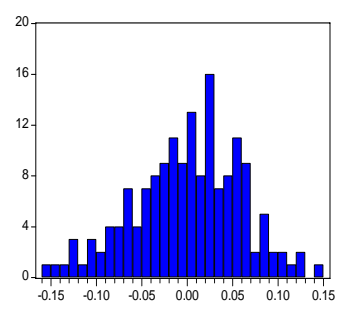


To further describe the return and risk characteristics, the skewness, kurtosis and JarqueBera (JB) statistics and test results of normality are also presented in Table 4. Skewness is a measure of asymmetry of the distribution of the series around its mean. The skewness of a symmetric distribution, such as the normal distribution, is zero. A positive (negative) skewness suggests a higher (lower) than normal distribution chance of higher (lower) than mean return. Kurtosis measures the peakedness or flatness of the distribution of the return series. A normal distribution has a kurtosis value equal to three. If it exceeds three, the distribution is peaked relative to the normal and if it is less than three, the distribution is flat relative to the normal. Hence, it captures the excess probability of abnormal returns, regardless of the sign of the returns. JB is a statistic for testing whether the series is normally distributed. It measures the difference of the skewness and kurtosis of the series with those from the normal distribution. A small probability value leads to the rejection of the null hypothesis of a normal distribution. An examination of Table 4 reveals several patterns. Listed real estate returns of Singapore, Hong Kong, Malaysia, Philippines, China and Japan display a positive skewness. However, only China is heavily positive skewed (skewness $=3.015)$. The other four Asian real estate indexes have a negative skewness each of between -0.751 (Thailand) and -0.097 (Indonesia). On the contrary, the US and UK real estate and market indexes exhibit small negative skewness.

The kurtosis for all Asian real estate indexes exceeds three. It ranges from 3.687 for Japan to 24.282 for China. Another point we observe is that all Asian real estate indexes display a kurtosis each higher than that of the NAREIT index (kurtosis = 3.242). In addition, the kurtosis of eight real estate index returns (other than Malaysia and Indonesia) is higher than their corresponding market index, especially for Thailand and China where their real estate series have significantly higher kurtosis than their market indexes. This implies that there is a high probability of abnormal returns, either positive or negative, when investing in Asian real estate securities. The only indexes with kurtosis less than three are the market index of Taiwan and the real estate and market indexes of the UK.

To further demonstrate the point of normality, the JB statistic is used. It clearly shows that except for Japan, the hypothesis of normality in real estate returns is firmly rejected for the other nine Asian markets. The corresponding JB statistics range between 12.82 (Indonesia) to 2466.83 (China), and are all statistically significant at the one-percent level. The market indexes of Japan, Taiwan and Thailand are also found to be normally distributed. Further, real estate and market returns in the UK and the NAREIT returns are normally distributed.

In summary, consideration of the third and fourth moments (i.e. skewness and kurtosis) shows that only one out of the ten Asian listed real estate markets are normally distributed (i.e. Japan). In addition, only four and three Asian real estate markets are normally distributed in the $1^{\text {st }}$ and $2^{\text {nd }}$ time periods respectively. These figures compare less favorably with market index (the corresponding numbers are 2, 5 and 5 respectively). The investment implication is that the usual mean-variance framework breakdown. For 
example, Markowitz optimization is not able to consider the case that investors prefer positively skewed returns to negatively skewed returns. In addition, note that the value of kurtosis is much higher than the corresponding value of skewness in many of the Asian markets. This implies that the main source of non-normality is kurtosis rather than skewness.

Compared with the developed US and UK markets, key findings of our results indicate that the developing Asian real estate markets report poorer investment returns, as well as a higher unconditional volatility and that the index of excess kurtosis is significantly higher since the 90's. Many Asian markets are characterized by land scarcity, high population density, lower yield and relatively high real estate values. Moreover, real estate security markets in Asia are generally aggressive with high and idiosyncratic risks. Finally, the 1997 Asian financial crisis and subsequent economic slowdown in the region have also worsened the underperformance of many Asian listed real estate markets; in contrast with the US and UK markets that were least hit by the crisis.

\section{TIME-VARYING SYSTEMATIC RISK AND JENSEN ABNORMAL RETURN}

To provide further evidence on the risk-return performance of Asian listed real estate, time-varying systematic risk (beta) and Jensen index of abnormal return performance (JI) using the traditional single index model over the full study period and for the two shorter sub-periods are estimated. This time-varying approach recognizes that the equity beta of real estate companies may vary over time. Hence, in order to obtain accurate, unbiased profiles of beta and JI profiles, a time-varying approach is used. JI is a measure of relative performance based on the security market line. A statistically significantly positive value for $\mathrm{JI}$ is regarded as evidence of superior risk-adjusted performance in comparison to the general market, whereas a significant negative value is evidence of inferior performance. The JI for a portfolio, $a l p h a_{1}$, is the intercept coefficient in a regression between excess returns for the portfolio, $\left[R_{i}-R_{f}\right]$, and excess returns for the market index, $\left[R_{m}-R_{f}\right]$; i.e. $\left[R_{i}-R_{f}\right]=$ alpha $_{1}+$ beta $_{1}\left[R_{m}-R_{f}\right]+$ error $_{I}$. The maximum likelihood estimation and Kalman Filter are employed to estimate time-varying JI and beta for each real estate series.

Table 7 reports the average monthly beta and JI for the 12 real estate stock markets. For the full period, the time-varying JI measures show that in 3 cases (China, Philippines and Singapore), abnormal performance is positive. However, analysis of the time-varying confidence intervals reveals only the China real estate has delivered superior risk-adjusted returns $(t=6.67)$. In contrast, abnormal returns of Philippines and Singapore real estate remain statistically indistinguishable from zero at the five-percent level $(\mathrm{t}=1.76$ and 0.63 for Philippines and Singapore respectively). Compared to shares, Thailand's real estate index provides insignificantly lesser abnormal returns. On the contrary, the real estate security markets for the remaining eight countries (including the USA and UK) display 
average negative abnormal returns, with under-performance being significant from zero. Thus, on average, real estate firms performed less well on a risk-adjusted basis than the market as a whole in the USA, the UK and Asian countries. With respect to the timevarying systematic risk estimates, the beta values for all Asian markets shows variation over time and the average betas are all above 1, reflecting that Asian property stock markets are more volatile and aggressive than the respective stock markets and high levels of gearing of their constituent real estate firms. In particular, Singapore and Hong Kong real estate markets top the list with beta values of approximately 1.397 and 1.256 respectively. In contrast, with beta values of less than 1 , the systematic volatilities of the US REITs and UK real estate stocks are lower than those of market portfolios.

\section{DIVERSIFICATION BENEFITS}

One key rationale for investing in Asian real estate is to achieve portfolio diversification in order to minimize investment risk. Several studies have demonstrated that the inclusion of real estate in mixed-asset portfolios provides more efficient portfolios than financial assets alone. To the extent that different categories of real estate are not subject to the same macroeconomic variables, diversification across geographic areas or real estate types will reduce the unsystematic risk of the portfolio. Hence, internationally diversified real estate portfolios would have substantially lower risk levels than purely domestic portfolios with the same level of return. As the Asian listed real estate markets are opened up to foreign investors, US investors may invest in the Asian real estate stocks with portfolio diversification in mind. One main question of interest posed by them will be; are there diversification benefits derived by investing in Asian real estate security markets?

To provide some answers, Table 8 displays the correlation matrix between the 12 real estate indexes for the full 1990-2003 period. Table 9 provides the correlation matrices for the 1990-1997 and 1997-2003 sub-periods. The lower the correlation coefficient, the greater the risk reduction benefits associated with diversification. If international diversification in real estate is beneficial, a low correlation between the real estate indexes of the countries is expected. 
Table 7: Monthly Time-varying Beta $(\beta)$ and Jensen Index $(\alpha)$

\begin{tabular}{|c|c|c|c|c|c|c|}
\hline \multirow{2}{*}{$\begin{array}{l}\text { Real estate } \\
\text { index }\end{array}$} & \multicolumn{3}{|c|}{ Average beta value } & \multicolumn{3}{|c|}{ Average JI value (t-stat) } \\
\hline & 1990:1-2003:6 & 1990:1-1997:6 & 1997:7-2003:6 & 1990:1-2003:6 & 1990:1-1997:6 & 1997:7-2003:6 \\
\hline Singapore & 1.397 & 0.969 & 1.711 & $0.0002(0.63)$ & $-0.0095\left(-6.87^{\mathrm{c}}\right)$ & $-0.0040\left(-1.94^{\mathrm{a}}\right)$ \\
\hline Hong Kong & 1.256 & 1.170 & 1.292 & $-0.0030\left(-8.89^{c}\right)$ & $-0.0015\left(-2.87^{\mathrm{c}}\right)$ & $-0.0049\left(-3.43^{c}\right)$ \\
\hline Philippines & 1.090 & - & 1.193 & $0.0029\left(1.76^{\mathrm{a}}\right)$ & - & $-0.0043(-1.43)$ \\
\hline Thailand & 1.299 & 1.049 & 1.362 & $-0.0087(-1.50)$ & $0.0105(0.97)$ & $-0.0253\left(-8.84^{c}\right)$ \\
\hline Indonesia & 1.188 & - & 1.372 & $-0.0032\left(-1.74^{\mathrm{a}}\right)$ & - & $-0.0139\left(-6.35^{c}\right)$ \\
\hline Korea & 0940 & 1.028 & 0.920 & $-0.0069\left(-13.51^{\mathrm{c}}\right)$ & $0.0012(0.65)$ & $-0.0397\left(-14.16^{\mathrm{c}}\right)$ \\
\hline Taiwan & 0.987 & - & 0.902 & $-0.0094\left(-10.75^{c}\right)$ & - & $-0.0214\left(-15.44^{\mathrm{c}}\right)$ \\
\hline Japan & 1.023 & 1.203 & 0.910 & $-0.0047\left(-2.18^{\mathrm{b}}\right)$ & $-0.0046\left(-3.32^{\mathrm{c}}\right)$ & $-0.0120\left(-6.91^{c}\right)$ \\
\hline US & 0.354 & 0.504 & 0.325 & $-0.0069\left(-13.49^{c}\right)$ & $-0.0106\left(-10.11^{c}\right)$ & $-0.0094\left(-9.02^{\mathrm{c}}\right)$ \\
\hline UK & 0.836 & 1.019 & 0.449 & $-0.0075\left(-19.05^{c}\right)$ & $-0.0112\left(-19.88^{c}\right)$ & $-0.0048\left(-4.83^{\mathrm{c}}\right)$ \\
\hline
\end{tabular}

c , b a - indicates two-tailed significance at the 1,5 and 10 percent levels respective 
Table 8: Correlation Matrix of Real Estate Indexes: Jan 1990- June $2003^{1}$

\begin{tabular}{|c|c|c|c|c|c|c|c|c|c|c|c|c|}
\hline $\begin{array}{l}\text { Correlation } \\
\text { Matrix }\end{array}$ & US & UK & Singapore & $\begin{array}{l}\text { Hong } \\
\text { Kong }\end{array}$ & Malaysia & Philippines & Thailand & Indonesia & China & Korea & Taiwan & Japan \\
\hline UK & 0.357 & 1.000 & & & & & & & & & & \\
\hline Singapore & 0.340 & 0.281 & 1.000 & & & & & & & & & \\
\hline Hong Kong & 0.239 & 0.277 & $0.749^{*}$ & 1.000 & & & & & & & & \\
\hline Philippines & 0.254 & 0.131 & $0.629^{*}$ & $0.561^{*}$ & 0.318 & 1.000 & & & & & & \\
\hline Thailand & 0.272 & 0.118 & $0.626^{*}$ & $0.541^{*}$ & $0.447^{* *}$ & $0.709^{*}$ & 1.000 & & & & & \\
\hline Indonesia & 0.010 & -0.037 & $0.434^{* *}$ & $0.448^{*}$ & 0.306 & $0.462^{* *}$ & $0.422^{* *}$ & 1.000 & & & & \\
\hline China & -0.006 & -0.042 & 0.043 & 0.011 & 0.185 & 0.012 & 0.082 & 0.065 & 1.000 & & & \\
\hline
\end{tabular}

${ }^{*},{ }^{* *}$ - indicates two-tailed significance at the 5 and 10 percent levels respectively 
Table 9: Correlation Matrix of Real Estate Indexes: Sub-Period 1: Jan 1990 - June $1997^{1}$

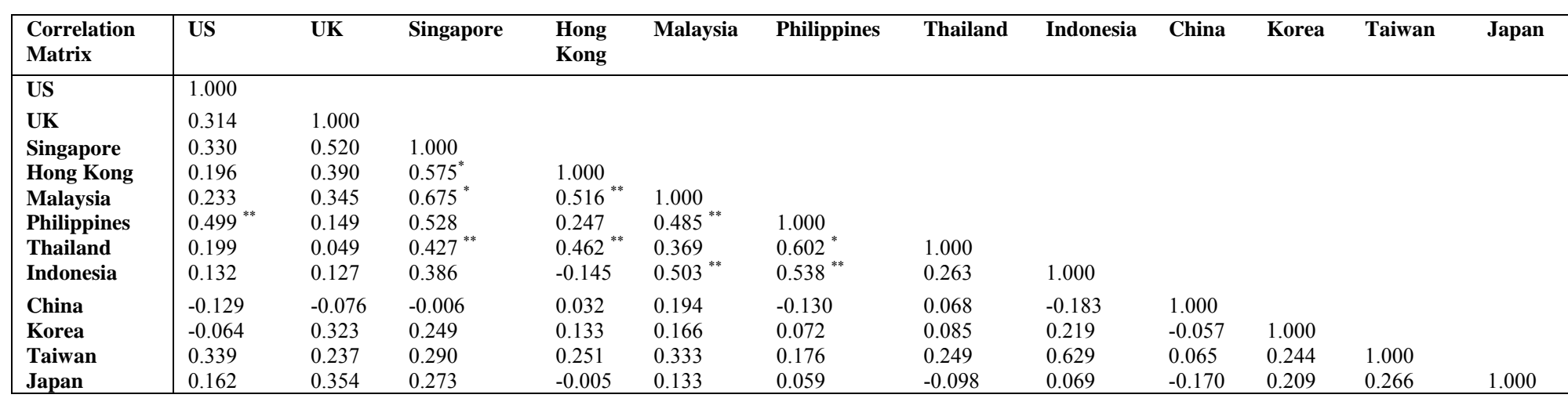


Sub-Period 2: July 1997- June 2003

\begin{tabular}{|c|c|c|c|c|c|c|c|c|c|c|c|c|}
\hline $\begin{array}{l}\text { Correlation } \\
\text { Matrix }\end{array}$ & US & UK & Singapore & Hong Kong & Malaysia & Philippines & $\begin{array}{l}\text { Thailand } \\
\end{array}$ & Indonesia & China & Korea & Taiwan & Japan \\
\hline US & 1.000 & & & & & & & & & & & \\
\hline UK & $0.420^{* *}$ & 1.000 & & & & & & & & & & \\
\hline Singapore & 0.363 & 0.172 & 1.000 & & & & & & & & & \\
\hline Hong Kong & 0.265 & 0.195 & $0.824^{*}$ & 1.000 & & & & & & & & \\
\hline Malaysia & 0.237 & 0.171 & $0.499^{* *}$ & $0.408^{* *}$ & 1.000 & & & & & & & \\
\hline Philippines & 0.199 & 0.119 & $0.642^{*}$ & $0.601^{*}$ & 0.292 & 1.000 & & & & & & \\
\hline Thailand & 0.326 & 0.189 & $0.698^{*}$ & $0.584^{*}$ & 0.488 & 0.740 & 1.000 & & & & & \\
\hline Indonesia & -0.010 & -0.062 & $0.438^{* *}$ & $0.458^{* *}$ & 0.302 & $0.463^{* *}$ & $0.445^{* *}$ & 1.000 & & & & \\
\hline China & 0.133 & -0.022 & 0.097 & -0.033 & 0.245 & 0.042 & 0.156 & 0.055 & 1.000 & & & \\
\hline Korea & 0.078 & 0.094 & 0.310 & 0.278 & 0.318 & 0.369 & $0.463^{* *}$ & 0.200 & 0.025 & 1.000 & & \\
\hline Taiwan & 0.232 & 0.091 & 0.250 & 0.380 & 0.282 & 0.275 & 0.262 & 0.062 & 0.004 & 0.051 & 1.000 & \\
\hline Japan & 0.021 & 0.193 & 0.209 & 0.204 & 0.033 & 0.321 & 0.439 & 0.136 & -0.034 & 0.217 & 0.036 & 1.000 \\
\hline
\end{tabular}

${ }^{1}$ The beginning data month for Philippines, Indonesia and China are October 1994, January 1996 and May 1993 respectively.

at

the

and

10

percent

levels

respectively. 
Over 1990-2003, the average of all the correlations among the 10 Asian real estate security markets is 0.238 . In addition, the average correlations between the Asian markets and the US and the UK are 0.176 and 0.161 respectively. In contrast, the respective stock market correlations are 0.364 (average correlations among the Asian general stock markets), 0.390 (average correlations between the stock markets of the US and Asian markets) and 0.349 (average correlations between the UK and Asian stock markets). Our results thus indicate that property stock returns are less internationally correlated than common stock returns. Consequently, international diversification works better for Asian property stocks than it does for general stocks. Our results are in agreement with those of Eichholtz (1996).

As noted above, the average correlations between the US and Asian real estate indexes (0.176) and between the UK and Asian real estate indexes are considerably low (0.161). This implies that substantial diversification benefits are possible by investing in the USAsian and UK-Asian portfolios. On a pairwise basis, the correlation coefficients between the NAREIT index and each Asian real estate index over the full period range between 0.006 (with China) and 0.340 (with Singapore). Similarly, the highest correlation coefficient between the UK FTSE real estate index and Asian real estate indexes is only 0.293 (with Japan).

In contrast, the correlation coefficients between the respective pairs of Asian real estate indexes are generally higher than those with the US and UK. This is reasonably expected due to the influence of some common events impacting the Asian region. Among the Asian markets, Singapore listed real estate index is highly correlated with the real estate indexes of Hong Kong (0.749), Malaysia (0.543), Philippines (0.629) and Thailand (0.626). Some other highly correlated Asian real estate index pairs are Hong Kong and Philippines (0.561), Hong Kong and Thailand (0.541) and Philippines and Thailand (0.709). Another observation is that the China real estate index has a negative correlation coefficient each with the NAREIT $(-0.006)$ and the FTSE real estate index $(-0.042)$ as well as very low positive correlations (between 0.011 and 0.185 ) with other Asian listed real estate indexes. Again this is not surprising, as China's economy in the past decade has been largely domestically driven, as opposed to many Asian countries, which are linked to the developed economies. Hence, China's growth has been largely independent of the other Asian countries. Finally, the correlation coefficient between the US and UK real estate indexes is 0.357 .

Recognizing that the above full period results span structural breaks such as the 1997 Asian financial crisis (Forbes and Rigobon, 2002), we also compare the cross-correlations over two shorter time periods (1990-1997 and 1997-2003). As the numbers from Table 9 show the correlations between the NAREIT index and six Asian real estate market indexes have improved for the sub-period 1997-2003. However, the correlations between the UK and eight Asian markets have reported a decrease over the same time period. This 
evidence suggests that the degree of interdependence between the US REIT market and Asian listed real estate markets has strengthened in recent years, possibly because of the development and establishment of successful REIT vehicles in Japan, Malaysia, Korea and Singapore. Even that is the case, the correlation coefficients between the NAREIT index and Asian real estate indexes are still considerably low, ranging between -0.010 (Indonesia) and Singapore (0.363). Clearly, the opportunities for Asian real estate diversification to improve portfolio performance exist for the US investors. Additionally, out of the 45 Asian real estate markets' bivariate correlations, 30 pairs emerge stronger in the later years. Hence, the linkages between Asian real estate markets appear to become stronger after the 1997 Asian financial crisis. Figure 2 graphs the 3-year rolling correlations between each Asian real estate security market and the US market over the full period. An in-depth investigation regarding the changing cross-market correlation as demonstrated from these graphs is probably a natural extension of this study.

Figure 2: Rolling Correlations
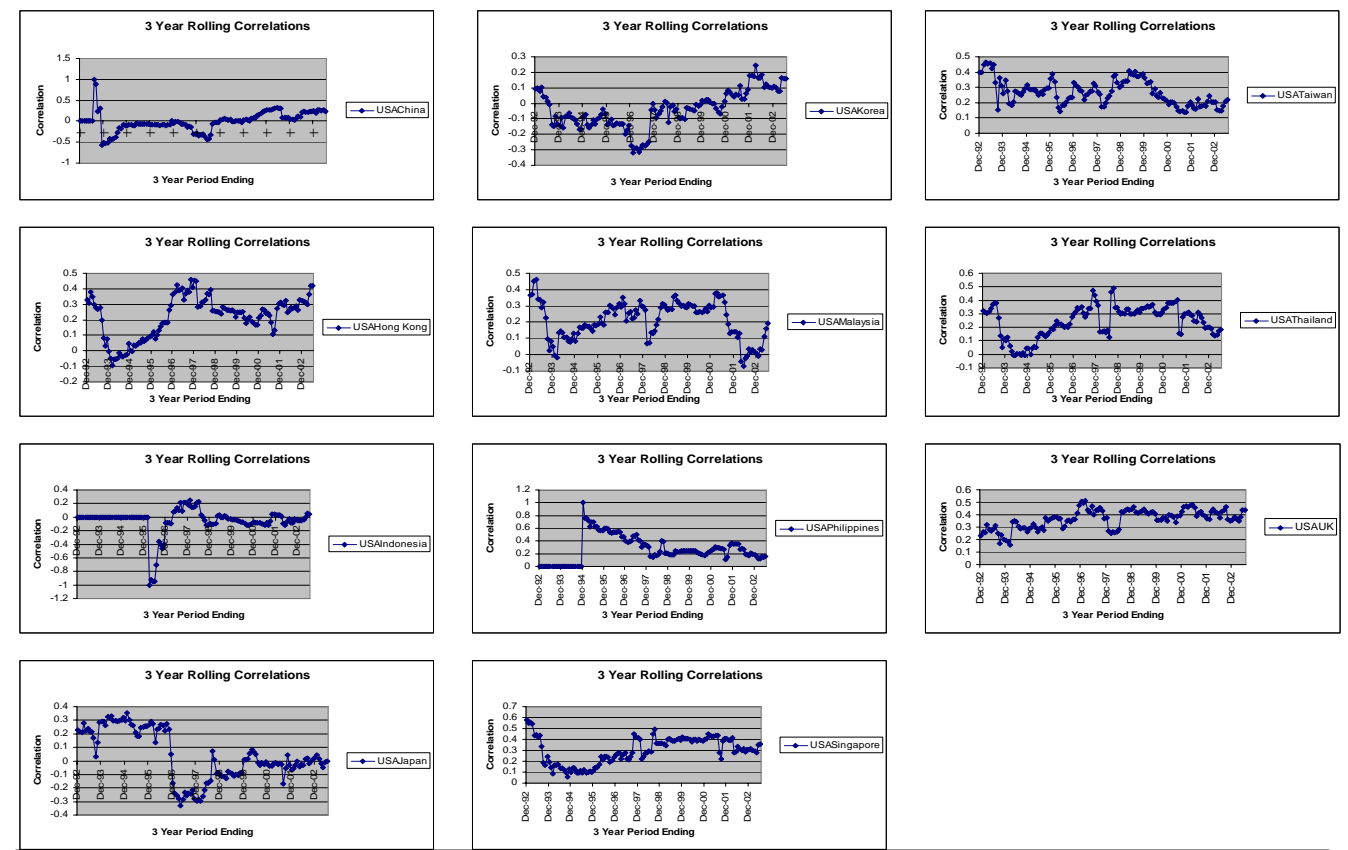

Finally, Figure 3 graphs the correlation coefficients between the respective domestic real estate and market indexes, as well as the correlations of the individual Asian real estate indexes with the market indexes of the USA and UK for the full 1990-2003 period. As can be seen, the correlation coefficients between the real estate stock and local market indexes for the 10 Asian markets are very high. They range from 0.938 for China to 0.714 for Taiwan. These figures compare favourably with 0.379 for the US market and 0.631 for the 
UK market. The findings suggest, unlike the USA and UK, the linkage between the performances of the real estate security market with those of the broader stock market is stronger in Asian countries. Accordingly, the case for separate allocations to international real estate securities is weakened. Except for Taiwan and Japan, the remaining eight Asian real estate indexes have a higher correlation each with the US market index than with the UK market index, again highlighting the stronger interdependence of the Asian real estate markets with the US equity market relative to the UK equity market. Nevertheless, the highest correlation coefficient between the Asian real estate indexes with the USA market index is 0.539 (between Singapore and USA). Thus, the addition of Asian real estate securities in a mixed-asset portfolio can still improve performance for the USA investors. 
Figure 3: Correlations of Real Estate Indexes (PI) and Market Index (MI): Jan 1990-June 2003 *

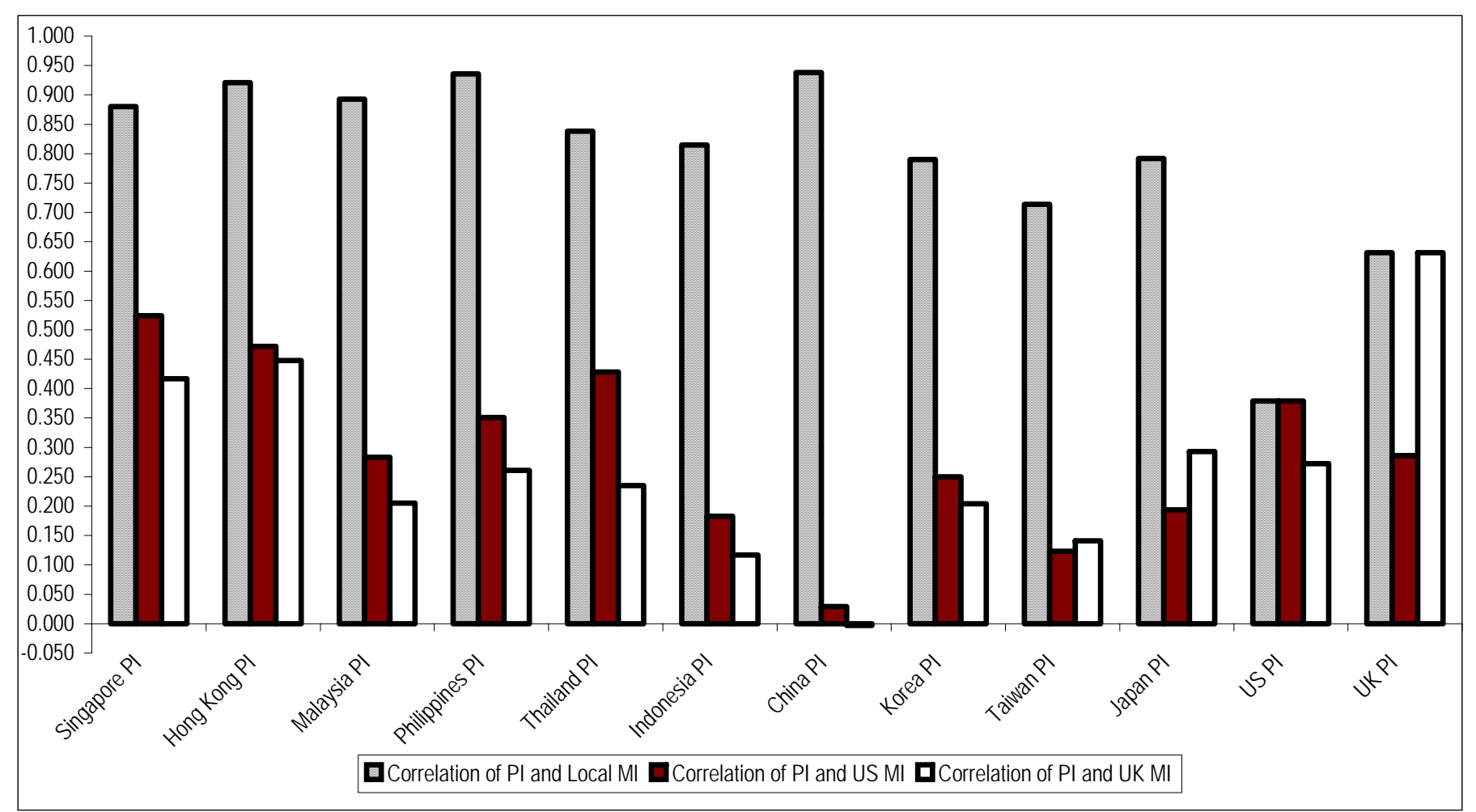

- The beginning data month for Philippines, Indonesia and China are October 1994, January 1996 and May 1993 respectively Pacific Rim Property Research Journal, Vol 12, No 3 


\section{CONCLUSION}

Listed real estate provides an important investment opportunity to obtain exposure to the stockmarket and the underlying real estate assets that comprise these portfolios. As such, it is important to assess the risk-return performance and diversification benefits that real estate securities are able to provide in a mixed-asset portfolio. Furthermore, the analysis of the risk and return profile of real estate stocks in ten Asian markets as well as the US REITs and UK real estate securities has shed some light on the attractiveness of Asian real estate securities as an investment option for international investors.

We find that Asian real estate stock markets, many of them are still developing, have not produced high levels of compound returns relative to the US REIT and UK real estate stock markets over the 1990-2003 time period. This is different from the stock market results of emerging markets presented in the earlier literature. They have also experienced a higher level of volatility compared to their USA and UK counterparts. Asset allocations using mean-variance optimization are difficult to carry out as many of the Asian listed real estate markets are not normally distributed. Furthermore, Asian real estate stocks have been able to provide diversification benefits when combined with the US and UK real estate securities. However, the case for separate allocations to international listed real estate is weakened by the high correlations that are found in Asian markets between their respective listed real estate and broader market indexes.

For the US real estate fund investors, the case for Asian listed real estate is probably mixed. While their historical returns, risk and risk-adjusted returns do not seem attractive since the 90's, as a whole they probably offer greater benefits of international diversification to the US investors, as investing in Asian real estate stock portfolios is probably more effective than investing in Asian common stock portfolios. Nevertheless, unlike the developed markets, investing in emerging Asian markets may incur higher transaction costs (including information costs and other institutional costs such as property rights system) and suffer from the illiquidity and information transparency problems. These hidden costs must be carefully considered when evaluating diversification benefits derived from investing in Asian real estate securities. Since investing interest in Asian real estate markets is intensifying as the regional upturn becomes more evident, our study advances the US investors' understanding regarding the dynamics of risk-return and diversification of Asian listed real estate and their contribution to investor performance. Finally, future work can incorporate the use of joint upside/downside risk-adjusted Sharpe and Sortino Indexes in a comprehensive investigation of the Asian real estate stock indexes with respect to the degree of integration or segmentation of the real estate with the broader equity markets, country by country, and the relevant factors in international investing. 


\section{REFERENCES}

Asabere, P., R. Kleiman and C. McGowan (1991), The Risk-Return Attributes of International Real Estate Equities. Journal of Real Estate Research, 6(2), 143-151.

Berkaert, C., C.B. Erb, C.R. Harvey and T.E. Viskanta (1997), What Matters for Emerging Equity Market Investments. Emerging Markets Quarterly: 17-46.

Bond, S., A. Karolyi and A. Sanders (2003), International Real Estate Returns: a Multifactor, Multicountry Approach. Real Estate Economics, 31(3): 481-500.

Chau, K.W., B. MacGregor and G. Schwann (2001), Price Discovery in the Hong Kong Real Estate Market. Journal of Property Research, 18(3): 187-216.

Conover, M., Friday, S. and S. Sirmans (2002), Diversification Benefits from Foreign Real Estate Investments. Journal of Real Estate Portfolio Management 8(1): 17-26.

Eaker, M., Grant D, and Woodard, N. (2000), Realized Rates of Return in Emerging Equity Markets. Journal of Portfolio Management, 26(3), 41-49.

Eichholtz, P. (1996), Does International Diversification Work Better for Real Estate than for Stocks and Bonds? Financial Analysts Journal, 52(1): 56-62.

Forbes, K. and R. Rigobon (2002), No Contagion, only Interdependence: Measuring Stock Market Co-movements, Journal of Finance, 57(5): 2223-61.

Garvey, R., Santry, G. and S. Stevenson (2001), The Linkages Between Real Estate Securities in the Asia-Pacific. Pacific Rim Property Research Journal 7(4): 240-258.

Gordon, J. and T. Canter (1999), Institutional Real Estate Securities: a Test of Capital Markets Integration. Journal of Real Estate Portfolio Management 5(2): 161-170.

Hartzell, D, Shulman, D.G. and Wurtzebach, C H (1987), Refining the Analysis of Regional Diversification for Income-Producing Real Estate. Journal of Real Estate Research, 2(2), 85-86.

Hu, J. and Mei, J. P. (1999), The Return and Risk of Emerging Markets Property Stock Indexes. Emerging Markets Quarterly, 3(1), 10-21.

Kallberg, J.G., Liu, C.H. and Pasquariello, P. (2002), Regime Shifts in Asian Equity and Real Estate Markets, Real Estate Economics, 30(2), 263-292

Liow, K. H. (2000), The Dynamics of the Singapore Commercial Property Market. Journal of Property Research, 17(4): 279-292. 
Liow, K. H. (2001a), The Long-Term Investment Performance of Singapore Real Estate and Property Stocks. Journal of Property Investment and Finance 19(2): 156-174.

Liow, K. H. (2001b), The Abnormal Return Performance of Singapore Property Companies. Pacific Rim Property Research Journal, 7(2): 104-112.

Lu, K., and Mei, J P (1999), The Return Distributions of Property Shares in Emerging Markets. Journal of Real Estate Portfolio Management, 5(2), 145-160.

Newell, G. and P. Acheampong (2001), The Dynamics of the Australian Property Trust Market Risk and Correlation Profile. Pacific Rim Property Research Journal, 7(4): 259270.

Newell, G. and K. W. Chau (1996), Linkages Between Direct and Indirect Property Performance in Hong Kong. Journal of Property Finance, 7(4): 9-29.

Newell, G. and J. MacFarlane (1996), What Does Property Trust Performance Tell Us About Commercial Property Returns? Australian Land Economics Review 2(1): 10-18.

Ross, T. A., and J. R. Webb (1985), Diversification and Risk in International Real Property Investment: An Empirical Study. International Property Investment Journal, 2(3), 359-377.

Steinert, M. and S. Crowe (2001), Global Real Estate Investment: Characteristics Portfolio Allocation and Future Trends. Pacific Rim Property Research Journal, 7(4): 223-239.

Wilson, P. and R. Zurbruegg (2003), International Diversification of Real Estate Assets: Is it Worth It? Evidence from the Literature, Journal of Real Estate Literature, 11(3): 259278. 